\title{
Pengembangan Media Komik Kerajaan Kanjuruhan Berbasis Online Dalam Mata Pelajaran Sejarah Indonesia
}

\author{
Septa Rahadian*, Hendri Setiawan \\ IKIP Budi Utomo Malang \\ *Corresponding author`s e-mail: septarahadian@budiutomomalang.ac.id
}

\begin{abstract}
So far, there are many concepts that need to be revised regarding studying history. At school, the lessons that are considered boring by students include history lessons. Most students find history lessons boring because they only focus on memorizing historical figures, events and places. Another thing that causes history lessons in schools to seem boring is that the teachers who teach are less able to revive the spirit or soul of history itself. In this study, the research method used is development with the main focus being the development of historical learning media which is presented in the form of comics which aims to make it easier for teachers to convey subject matter and help students understand the material. From the results of this study as much as $80 \%$ of the total number of class participants were able to absorb well the material presented so that conclusions could be drawn through comics the learning process can activate the seriousness of students in learning, learning media in the form of comics that are entertaining and light make students tend to enjoy reading or the story instead of spending their time reading school textbooks.
\end{abstract}

Keywords: comic; online; Kanjuruhan

Abstrak: Selama ini banyak konsep yang perlu direvisi mengenai belajar sejarah. Di sekolah biasanya pelajaran yang dianggap membosankan oleh siswa diantaranya adalah pelajaran sejarah. Kebanyakan siswa menganggap pelajaran sejarah membosankan karena hanya berkutat pada hafalan tokoh, peristiwa dan tempat bersejarah. Hal lain yang menyebabkan pelajaran sejarah di sekolah terkesan membosan karena guru yang mengajar kurang mampu dalam menghidupkan spirit atau jiwa sejarah itu sendiri. Dalam penelitian ini metode penelitian yang digunakan adalah pengembangan dengan fokus utamanya adalah pengembangan media pembelajaran Sejarah yang disajikan dalam bentuk komik yang bertujuan untuk mempermudah guru menyampaikan materi pelajaran dan membantu peserta didik dalam memahami materi. Dari hasil penelitian ini sebanyak $80 \%$ dari total jumlah peserta kelas mampu menyerap dengan baik materi yang disampaikan sehingga dapat ditarik kesimpulan melalui komik proses pembelajaran dapat mengaktifkan keseriusan peserta didik dalam pembelajaranya, media pembelajaran berupa komik yang menghibur dan ringan membuat peserta didik cenderung lebih menyenangi bacaan atau cerita tersebut dibandingkan mengunakan waktu mereka untuk membaca buku pelajaran sekolah.

Kata kunci: komik; online; Kanjuruhan

\section{Pendahuluan}

Jepang Belajar menduduki peran yang sangat penting baik dalam konteks kehidupan umat manusia maupun dalam konteks kehidupan semua mahuk hidup lainnya di bumi ini, agar kehidupan mereka dapat terus berlangsung. Binatang yang secara alami dibekali insting untuk mempertahankan hidupnya, tenyata juga tidak lepas dan keharusan belajar. Sebagaimana disimpulkan oleh Hergenhahn dan Olson (2010), kemampuan one-trial learning (belajar coba satu kali) pada binatang merupakan pelengkap dari instingnya agar mereka dapat mempertahankan kehidupan dirinya. Demikian juga halnya dengan manusia, agar mereka bias terus mempertahankan hidupnya mereka dituntut untuk terus belajar dan 
belajar. Namun demikian, tidak semudah menyebutkannya, untuk merumuskan dan mendefinisikan apa itu "belajar" ternyata memerlukan usaha yang hati-hati. Hingga saat ini telah banyak para ahli yang telah mencoba merumuskannya, namun rumusan mereka selalu dipandang masih mengandung kekurangan, khususnya pada aspek-aspek yang dikandungnya. Terjadinya perubahan zaman juga membuat berbagai perubahan cara-cara orang memahami arti dan hakikat belajar. Suatu kenyataan yang terjadi dalam kehidupan pembelajaran dewasa ini bahwa hasil pembelajaran banyak dipengaruhi oleh proses pembelajaran siswa, perencanaan pembelajaran, dan penataan lingkungan baik belajar maupun sosial dalam kelas, yang selanjutnya akan berdampak pada kualitas hasil belajar siswa.

Pelaksanaan pembelajaran kurang memberdayaan lingkungan belajar, lingkungan belajar siswa disekolah baik di kelas maupun dilingkungan kelas kurang ditata sedemikian rupa yang mendukung proses pembelajaran di kelas, dan para guru dalam mengajar menggunakan model atau pendekatan pembelajaran mengikuti yang sedang dikembangkan namun tidak dibarengi dengan setting kelas yang dituntut oleh model atau pendekatan yang digunakan tersebut. Hal tersebut dapat disiasati dengan mengembangkan media pembelaran yang komunikatif dan interaktif. Sejarah merupakan cerita tentang pengalaman kolektif suatu komunitas atau kebangsaan di masa lampau. Pada pribadi pengalaman membentuk kepribadian seseorang dan sekaligus menentukan identitasnya. Bangsa yang tidak mengenal sejarahnya dapat diibaratkan seorang individu yang telah kehilangan memorinya, ialah orang yang lupa atau sakit jiwa, maka dia kehilangan kepribadian atau identitasnya (Kartodirdjo, 2008).

Selama ini banyak konsep yang perlu diperbaiki mengenai belajar sejarah. Di sekolah biasanya pelajaran yang dianggap membosankan oleh siswa diantaranya adalah pelajaran sejarah. Kebanyakan siswa menganggap pelajaran sejarah membosankan karena hanya berkutat pada hafalan tokoh, peristiwa dan tempat bersejarah. Hal lain yang menyebabkan pelajaran sejarah di sekolah terkesan membosan karena guru yang mengajar kurang mampu dalam menghidupkan spirit atau jiwa sejarah itu sendiri. Materi yang diajarkan lebih berkutat pada tekstual bukan kepada kontekstual, jadi mengulang ulang materi atau pengetahuan yang sudah ada di buku atau diketahui oleh siswa. Dampaknya siswa menjadi kehilangan semangat dalam belajar sejarah. Dengan mengembangkan media pembelajaran sejarah yang menarik diharapkan siswa memiliki ketertarikan terhadap materi yang diajarkan khususnya pelajaran sejarah. Sumber belajar yang hanya berasal dari guru dan buku teks tidaklah cukup, sehingga perlu cara baru untuk menyampaikan materi ajar 
dalam sistem yang mandiri maupun terstruktur. Oleh karena itu, perlu suatu pengembangan media pembelajaran yang lebih inovatf, efektif, fleksibel, dan efisien. Media komik merupakan salah satu media visual yang dirancang sebagai media pembelajaran yang memiliki kelebihan-kelebihan yang sulit didapatkan dari media lain. Media pembelajaran Sejarah yang disajikan dengan komik mempermudah guru menyampaikan materi pelajaran dan membantu peserta didik dalam memahami materi. Komik merupakan proses pembelajaran yang dapat mengaktifkan keseriusan peserta didik dalam pembelajaranya, Sifat media komik yang menghibur dan ringan membuat peserta didik cenderung lebih menyenangi bacaan tersebut dibandingkan mengunakan waktu mereka untuk membaca buku pelajaran sekolah.

Dibandingkan dengan buku pelajaran sekolah pada umumnya, komik mempunyai beberapa kelebihan sehingga lebih memikat peserta didik untuk mau membacanya. Media komik yang akan dikembangkan dipilih dengan mempertimbangkan berbagai alasan, yaitu: 1) anak-anak pada umumnya suka membaca komik, 2) media komik mampu menyajikan gambaran cerita secara konkret dengan ilustrasi gambar dan dialog, 3) penggunaan media komik yang mudah baik bagi guru maupun siswa, 4) komik bisa dibaca kapan saja dan dimana saja. Menurut Kamus Besar Bahasa Indonesia (KBBI), Komik adalah cerita bergambar (dalam majalah, surat kabar, atau berbentuk buku) yang umumnya mudah dicerna dan lucu (Depdikbud, 2001). Maestro komik barat yang bernama Will Eisner pada tahun 1986 dalam bukunya berjudul Comics and Sequential art mendefinisikan komik sebagai "susunan gambar dan kata-kata untuk menceritakan sesuatu atau mendramatisasi suatu ide", Kemudian pada tahun 1996, Will Eisner mengeluarkan buku terbarunya yang berjudul Graphic Storytelling, dalam buku itu ia kembali mendefinisikan komik sebagai "tatanan gambar dan balon kata yangt berurutan, dalam sebuah buku komik".

Pada tahun 1993, seorang pembuat komik dari Amerika yang bernama Scott McCloud, dalam bukunya yang berjudul Understanding Comics, menjelaskan bahwa komik adalah gambar-gambar dan lambang-lambang lain yang terjuktaposisi (berdekatan, bersebelahan) dalam urutan tertentu yang bertujuan untk memberikan informasi atau untuk mencapai estetis dari para pembaca (Maharsi, 2011). Di Jepang komik dikenal dengan nama manga (di Korea dan Cina disebut dengan istilah manhwa, pen). Dan orang yang membuat manga disebut dengan istilah mangaka (A.R. Studio, 2013). Sementara di Indonesia profesi pembuat komik disebut dengan beberapa istilah, yakni komikus, pelukis cergam (cerita bergambar), seniman cergam, atau cergamis (Bonneff, 2008). Dari pengertian-pengertian diatas dapat kita tarik kesimpulan bahwa komik adalah susunan gambar berurutan beserta dengan teks yang memiliki alur cerita dan tujuan yang ingin disampaikan pembuatnya. 
Dikarenakan komik memiliki banyak pesan berbeda yang ingin disampaikannya, maka komik sendiri terbagi menjadi dua yakni: (1) berdasarkan bentuknya dan (2) berdasarkan ceritanya. Indira Maharsi, M.Sn., salah seorang dosen di Institut Seni Indonesia (ISI) dalam bukunya yang berjudul "Komik: Dunia Kreatif Tanpa Batas" (2011), menjelaskan kedua kategori tersebut sebagai berikut: Komik berdasarkan berdasarkan bentuknya terbagi menjadi 5 kategori, yakni: (a) Komik Strip (Comic Strips), yang masih terbagi lagi menjadi: (1) komik strip bersambung dan juga (2) kartun komik; (b) Buku Komik (Comic Book); (c) Novel Grafis (Graphic Novel); (d) Komik Kompilasi; dan (e) Komik Online (Web Comic). Berikut penjelasan dari amsing-masing kategori tersebut: Istilah komik strip (comic strips) merujuk pada komik yang terdiri dari beberapa panel saja dan biasanya muncuul di surat kabar ataupun majalah.

Comic Book atau buku komik adalah komik yang disajikan dalam bentuk buku yang tidak merupakan bagian dari media cetak lainnya. Kemasan comic book ini lebih menyerupai majalah dan terbit secara rutin. Buku Komik yang pertama kali muncul adalah The Funnies pada tahun 1929. Setelah itu bermunculan Komik Buku yang diterbitkan oleh DC Comics yang pada perkembangan selanjutnya menjadi penerbit komik terbesar di dunia disamping Marvel Comics yang muncul belakangan dengan tokohnya yang terkenal yaitu Spiderman. Komik online, sesuai dengan namanya maka komik ini menggunakan media internet dalam publikasinya. Dengan memakai situs web maka komik jenis ini hanya menghabiskan biaya yang relatif murah dibandingkan media cetak dan jangkauannya sangat luas tak terbatas. Komik ini muncul seiring dengan munculnya cyberspace di dunia teknologi komunikasi. Dahulu komik dicap sebangsa 'racun' karena dianggap pesan yang dihadirkannya tidak mengandung nilai-nilai edukatif sama sekali. Namun sekarang, komik justru dipakai sebagai penyampai pesan yang bermuatan edukatif dari tingkat TK, SD hingga perguruan tinggi.

Menurut Marcel Bonneff (2008) komik adalah cara ampuh untuk menyampaikan berbagai gagasan kepada anak-anak dan publik, terutama di bidang informasi, periklanan dan juga pendidikan. Di Indonesia banyak institusi pendidikan, agama dan pemerintah yang menggunakan komik sebagai media didaktis (pembelajaran). Komik memang masuk dalam kategori media pembelajaran 'multimedia'. Multimedia sebagai sarana pendidikan memiliki unsur gabungan dari cetak atau teks, audio, video, slide, siaran radio, siaran televisi, dll, sebagai media pembelajaran. Menurut penelitian Bobbi de Porter dan Mike Hernacki (1999:16), penggagas Quantum Learning, mengungkapkan jika metode quantum learning merupakan metode pembelajaran yang mencakup aspek global. Aspek global dimasukkan untuk menutupi kekurangan dalam gaya belajar dari masing-masing siswa sehingga dapat 
mempercepat proses penyerapan informasi yang disampaikan sesuai dengan kecenderungan siswa dalam belajar. Dalam pembelajaran sejarah menggunakan media Visualisasi dengan menggunakan perangkat multimedia adalah salah satu solusi dalam mengatasi ketidakmapuan siswa dalam membaca buku teks atau narasi mengenai sejarah. Karena visualisasi adalah salah satu cara terbaik yang dapat dilakukan untuk mengkonkretkan suatu yang abstrak. Gambar dua dimensi atau model tiga dimensi adalah model visualisasi yang dapat dijadikan pendekatan yang berguna dalam proses belajar (Ariani dan Haryanto, 2010). Komik sendiri merupakan bagian dari multimedia. Ia memiliki bentuk visual berupa dua dimensi dalam bentuk cetak atau digital. Jika digunakan sebagai media pembelajaran maka komik dapat memberikan sumbangsih pemahaman sebesar 20\% (penglihatan) dan 10\% (membaca) kepada penggunanya menurut penelitian Bobbi de Porter.

Pendapat ini juga diperkuat oleh keterangan dari Heru Dwi Waluyanto (2005) seorang dosen Desain Komunikasi Visual (DKV), Universitas Kristen Petra, dalam tulisannya yang berjudul 'Komik sebagai Media Komunikasi Visual Pembelajaran', sebagai berikut: Niken Ariani dan juga Dany Haryanto (2010), pernah melakukan sebuah ujicoba dengan menggunakan media komik sebagai media pembelajaran di salah satu SMP Negeri di Kota Malang. Komik tersebut digunakan dalam mata pelajaran 'sejarah' yang diperbandingkan dengan metode pembelajaran konvensional. Dari hasil penelitian itu didapatkan hasil sebesar 66,4\% siswa menyerap pelajaran dengan cara metode pembelajaran secara konvensional. Sedangkan dengan menggunakan media pembelajaran berupa komik, para siswa dapat menyerap pelajaran hingga $84,07 \%$ prosentasenya. Contoh penelitian tersebut membuat kita menyimpulkan bahwa rata-rata orang Indonesia butuh media pembelajaran visual untuk memudahkan penyerapan dari materi pelajaran, terutama pada mata pelajaran yang dianggap sulit dan membosankan seperti sejarah. Dan disini komik menjadi salah satu solusi dalam menghadapi proses pembelajaran di era milenial saat ini.

\section{Metode}

Penelitian ini menggunakan metode Research and Development. Kegiatan awal sebelum melakukan pengembangan terhadap media pembelajaran dengan menggunakan komik adalah analisis kebutuhan. Analisis kebutuhan di lakukan observasi awal pada kelas X SMK Putra Indonesia Malang yang terdiri dari dua jurusan yakni Farmasi Industri berjumlah 35 siswa dan jurusan Kimia Indsutri yang berjumlah 30 orang ditemukan bahwa tidak adanya media pembelajaran yang menarik perhatian peserta didik sehingga banyak peserta didik banyak yang bercanda dengan teman sebangkunya saat pembelajaran sedang berlangsung. Sebagai informasi jika pembelajaran sejarah khususnya di jenjang SMK hanya 
dilaksanakan pada kelas X saja, sehingga rangkuman materi yang begitu padat dan banyak cenderung menyebabkan siswa enggan untuk membaca buku teks, oleh karena itu peneliti ingin menggunakan media pembelajaran berupa komik sebagai acuan pembelajaran agar peserta didik lebih termotivasi dan lebih kreatif dalam pembelajaran. Tahap perencanaan produk terdiri dari beberapa tahap yaitu, pengembangan komik, menulis naskah, menggambar komik. Adapaun draft desain pengembangan produknya dapat dilihat pada peta konsep dibawah ini.

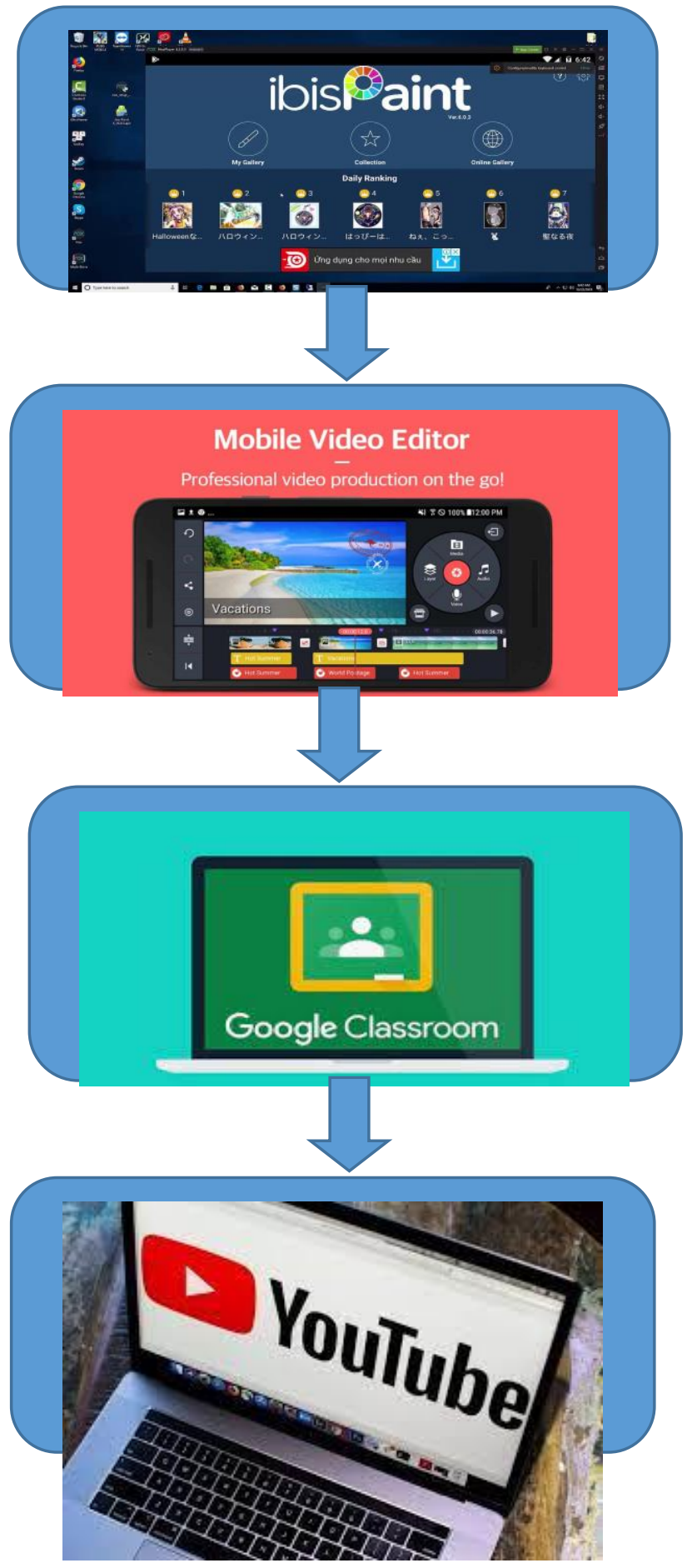


Tahap awal dari desain media pembelajaran ini adalah proses menggambar komik dengan menggunakan software ibispaintx serta proses finishing menggunakan software kinemaster, kemudian dipubliskasikan di Googleclassroom dan media social. Adapun media social yang digunakan adalah Youtube. Youtube dipilih sebagai media sosial yang paling mudah untuk diakses dan paling sering diakses oleh khalayak. Validasi desain merupakan proses kegiatan untuk menilai rancangan produk. Proses validasi dilakukan secara dua tahap. Tahap yang pertama adalah validasi ahli sejarah. Validasi ini dilaksanakan untuk mengetahui kebenaran alur cerita sejarah yang telah dibuat dalam media pembelajaran berbasis komik online tersebut. Sedangkan tahap yang ke dua adalah validasi ahli media. Validasi ini adalah untuk mengetahui apakah media pembelajaran yang sudah di desain tersebut dapat memenuhi standart dan kriteria yang baik dan sesuai sebagai media pembelajaran sejarah berbasis komik online.

Setelah desain produk divalidasi oleh ahli materi, dan ahli media maka dapat diketahui kelemahan dari komik tersebut. Kelemahan tersebut kemudian diperbaiki untuk mengahsilkan produk yang lebih baik lagi. Bila perubahan-perubahan yang dilakukan untuk menghasilkan produk baru tersebut sangat besar dan mendasar, evaluasi formatif kedua perlu dilakukan. Tetapi, bila perubahan ini tidak terlalu besar dan tidak mendasar, produk baru itu siap dipakai dilapangan sebenarnya. Produk yang telah selesai dibuat, selanjutnya diuji cobakan dalam kegiatan pembelajaran. Untuk uji coba produk dilakukan dengan cara menampilkannya melalui media sosial Youtube. Hal ini dilaksanakan karena proses pembelajaran masih dilaksanakan dengan sistem daring sebagai dampak dari adanya pandemi covid 19.

\section{Hasil Dan Pembahasan}

Kegiatan utama pada tahap ini adalah menganalisis kebutuhan berupa karakteristik peserta didik dan identifikasi kebutuhan di kelas X SMK Putra Indonesia Malang. Pada observasi awal yang dilakukan di kelas X SMK Putra Indonesia Malang peneliti mendapati kebanyakan peserta didik tidak tertarik untuk memerhatikan pelajaran dan melakukan kegiatan lain seperti mengajak teman di sampingnya bercerita dan keluar masuk kelas. Saat diberi pertanyaan, banyak peserta didik yang tidak menjawab dan hanya menunggu peserta didik yang lain untuk menjawab. Peserta didik juga kurang terlibat aktif dalam pembelajaran. Oleh karena itu diperlukan media pembelajaran lain yang dapat membuat peserta didik lebih tertarik dan termotivasi untuk belajar. Salah satu media yang dapat digunakan yaitu media pembelajaran berbasis komik. Media pembelajaran berbasis komik memungkinkan adanya 
peran aktif peserta didik dalam pembelajaran dengan cara yang lebih menarik. Tahap design (desain) bertujuan untuk menyiapkan prototipe I dari produk, dalam hal ini media pembelajaran berbasis komik. Fokus utama yaitu menetapkan indikator pembelajaran yang sesuai dengan kompetensi dasar KD 3.6 yakni menganalisis perkembangan kehidupan masyarakat, pemerintahan, dan budaya pada masa kerajaan-kerajaan Hindu dan Buddha di Indonesia serta menunjukkan contoh bukti-bukti yang masih berlaku pada kehidupan masyarakat Indonesia masa kini dengan materi Kerajaan Kanjuruhan membuat sketsa cover dan isi komik, merancang skenario pembelajaran. Pada tahap ini semua yang telah dirancang ditahap desain mulai dikembangkan. Peneliti mulai membuat alur cerita dan menyusun gambar dengan alur yang menarik yang di dalamnya mencakup materi asal usul berdirinya Malang dan beridirinya Kerajaan Kanjuruhan.

Pembuatan media pembelajaran berbasis komik ini dilakukan dengan menggunakan aplikasi Ibispaint x sedangkan untuk mengedit videonya menggunakan Kinemaster. Media pembelajaran berbasis komik yang telah dikembangkan diimplementasikan pada situasi yang nyata yaitu di kelas. Dalam proses pembelajaran menggunakan media ini. Tahap implementasi dilaksanakan pada tanggal 25 Agustus 2020 yang dikhususkan pada kelas X SMK Putra Indonesia Malang yang ber alamat Jalan Barito No 6. Malang Jawa Timur. Jumlah peserta didik 30 orang. Pelaksanaan proses pembelajaran pada saat ini dilakukan dengan metode daring karena adanya pandemic Covid 19, Jadi Proses Pembelajaran Menggunakan Media Googleclassroom dan Youtube, untuk berinteraksi dengan siswa. Dalam penelitian ini materi yang diangkat bertemakan mengenai Kerajaan Kanjuruhan, hal ini sesuai dengan Kurikulum yang dipakai di SMK Putra Indonesia Malang yakni Kurikulum 2013 revisi dimana Kompetensi Dasar yang dipakai adalah KD 3.6 yang isinya adalah, menganalisis perkembangan kehidupan masyarakat, pemerintahan, dan budaya pada masa kerajaan-kerajaan Hindu dan Buddha di Indonesia serta menunjukkan contoh bukti-bukti yang masih berlaku pada kehidupan masyarakat Indonesia masa kini.

Berdasarkan KD tersebut maka disusunlah indikator pembelajaran yakni peserta didik mampu menjelaskan proses berdirinya kerajaan Kanjuruhan dengan latar belakang kota Malang sebagai lokasi dimana berdirinya kerajaan Kanjuruhan. Peneliti memilih KD dan indikator tersebut dengan pertimbangan Kota Malang merupakan Lokasi yang dekat dengan peserta didik sekaligus sebagai tempat berdirinya Kerjaan kanjuruhan akan tetapi belum begitu banyak yang tahu bagaimana atau asal usul munculnya kota Malang dan Kerajaan Kanjuruhan. Peneliti bermaksud untuk membantu peserta didik dalam memahami Proses munculnya kota Malang dan proses Berdirinya Kerajaan Kanjuruhan melalui media 
pembelajaran berbasis komik. Tahap desain adalah tahap dimana peneliti merancang media yang akan dikembangkan. Komik digunakan sebagai media pembelajaran karena dalam pembelajaran sejarah penggunaan media bergambar dan audio visual akan lebih mudah dalam penyampaian alur cerita mengenai perkembangan kota Malang pada masa awal dan munculnya Kerajaan Kanjuruhan, sehingga pemahaan peserta didik mengenai asal usul kota Malang dan perkembangan Kerajaan Kanjuruhan dapat dengan mudah dipahami oleh peserta didik. Tahap implementasi adalah tahap di mana media telah diuji cobakan di dalam kelas. Pada tahap ini media pembelajaran komik dibagikan kepada peserta didik dan digunakan sebagai media pembelajaran. Pelaksanaan proses pembelajaran pada saat ini dilakukan dengan metode daring karena adanya pandemic Covid 19, Jadi Proses Pembelajaran Menggunakan Media Googleclassroom dan Youtube, untuk berinteraksi dengan siswa.

Keefektifan media pembelajaran berbasis komik ini dapat dilihat dari persentase skor hasil belajar Sejarah peserta didik kelas X SMK Putra Indonesia Malang. Hasil tes peserta didik menunjukkan banyaknya peserta didik yang memeroleh pemahaman sangat tinggi sebanyak 57\%. Peserta didik dengan pemahaman tinggi sebanyak 28\%. Peserta didik dengan pemahaman sedang sebanyak $4 \%$ dan peserta didik dengan pemaham rendah dan sangat rendah sebanyak $0 \%$. Pengukuran presentase tersebut diperoleh dari hasil post test dimana setelah penggunaan media pembelajaran sejarah berbasis komik online tersebut dilaksanakan hasilnya sekitar lebih dari 40 siswa jumlah total dari 65 siswa kelas X mendapatkan nilai di atas 85 , jauh lebih baik dibandingkan saat penyampaian materi menggunakan metode konvensional atau menggunakan buku teks. Adapun presentase ketuntasan hasil belajar Sejarah setelah menggunakan media pembelajaran berbasis komik ini dapat dilihat dari persentase skor hasil belajar sejarah peserta didik yaitu 86\% peserta didik berhasil mencapai ketuntasan sedangkan 14\% belum tuntas. Kriteria keefektifan terpenuhi jika peserta didik yang mencapai ketuntasan lebih besar atau sama dengan (80\%).

Setelah pembelajaran selesai peneliti membagikan angket kepada peserta didik yang telah diajar. Hal ini dimaksudkan untuk mengetahui respons peserta didik terhadap media pembelajaran komik. Kepraktisan media berbasis komik yang dikembangkan dapat diukur dengan menggunakan analisis data melalui angket respons peserta didik. Angket ini diambil saat kegiatan pembelajaran telah selesai. Angket ini berupa daftar pernyataan yang disusun dengan 4 butir pernyataan alternatif untuk respons peserta didik yaitu "sangat setuju", "setuju", "tidak setuju", dan "sangat tidak setuju". Hasil uji coba responden (angket respons peserta didik) menunjukkan bahwa banyak peserta didik yang minat terhadap media pembelajaran berbasis komik. Berdasarkan data yang telah diperoleh dari setiap tahap 
pengembangan di atas maka dapat disimpulkan bahwa perangkat media pembelajaran berbasis komik ini dapat dikatakan valid, praktis dan efektif.

\section{Kesimpulan}

Dari hasil penelitian ini diperoleh sebuah penjelasan jika penggunaan media pembelajaran berbasis komik adalah sarana yang tepat untuk memvisualisasikan cerita sejarah. Disamping itu kita juga dapat menyampaikan berbagai gagasan dan kebaruan mengenai cerita sejarah tersebut kepada anak-anak Kedepannya diharapkan semakin banyak media pembelajaran sejarah yang menggunakan komik sebagai media didaktis (pembelajaran). Dengan mengembangkan media pembelajaran sejarah kerajaan Kanjuruhan berbasis komik, dapat meingkatkan keaktifan, kemauan dan pemahaman peserta didik dalam mengikuti proses pembelajaran, khususnya dalam pembelajaran Sejarah.

\section{Daftar Pustaka}

A.R. Studio. (2013). Drawing Magic Menggambar Manga. Cetakan Ke-2. Jakarta: Mediakita. Abidin, Jefri Marzal, dan Rohati. "Pengembangan Media Pembelajaran Matematika Interaktif Berbasis Android untuk Menumbuhkan Motivasi belajar Anak Disleksia pada Materi Eksponensial di Kota Jambi." Edumatica 04 (02): 66-76

Ariani, N. dan Haryanto, D. (2010). Pembelajaran Multimedia di Sekolah: Pedoman Pembelajaran Inspiratif, Konstruktif dan Prospektif. (Editor: Ardhiawan, Program Director \& Editor RCTI). Jakarta: PT. Prestasi Pustakaraya Publisher.

Bonneff, M. (2008). Komik Indonesia (Les Bandes Desinées Indonesiennes). (Penerjemah: Rahayu S. Hidayat). Cetakan Ke-3. Jakarta: Kepustakaan Populer Gramedia (KPG).

Departmen Pendidikan dan Kebudayaan (Debdikbud). (2001). Kamus Besar Bahasa Indonesia (K.B.B.I.) Edisi Ketiga. Jakarta: Balai Pustaka.

Desriana, Barbara dan C. Asri Budiningsih. (2018). Audiobook Pembelajaran Mata Kuliah Literatur Berdasarkan Perspektif Behavioral untuk MeningkatkanPemahaman Bahasa Jerman. Jurnal JITP. Diambil pada tanggal 20 Maret 2019, dari https://journal.uny.ac.id/index.php/jitp/article/view/13377/11781.

Dimyati, Mudjiono. (2006). Belajar dan Pembelajaran. Jakarta: Penerbit Rineka

Hergenhahn, B.R dan Olson, Matthew H. (2010). Theories of Learning. Jakarta: Kencana PRenada Media Group. Jakarta.

Kartodidjo, Sartono (2008). Pendekatan Ilmu Sosial dalam Metodologi Sejarah. Jakarta: Gramedia.

Maharsi, I. (2011). Komik: Dunia Kreatif Tanpa Batas. Yogyakarta: KATA BUKU.

Waluyo, H.D. (2005). 'Komik sebagai Media Komunikasi Visual Pembelajaran'. Dalam Jurnal Nirmana, Vol. 07, No. 01, Edisi Januari 2005. Hal. 44-55. Surabaya: Jurusan Desain Komunikasi Visual, Fakultas Seni dan Desain, Universitas Kristen Petra. 